\title{
THEORETICAL-CRITICAL DIALOGUES ON AUTHORITARY MEMBERSHIP AND EVALUATION AT PNAIC
}

\section{DIÁLOGOS TEÓRICO-CRÍTICOS SOBRE A ADESÃO E A AVALIAÇÃO AUTORITÁRIAS NO PNAIC}

\author{
DIÁLOGOS TEÓRICO-CRÍTICOS SOBRE ADHERENCIA Y EVALUACIÓN AUTORITARIA EN EL PNAIC
}

\author{
Crisley Monteiro Olarte ${ }^{1}$
} Isabella Fernanda Ferreira²

\begin{abstract}
The National Pact for Literacy at the Right Age (PNAIC) aims to alphabetize children until the third year of elementary school. It is subdivided into four axes: Continuing education, Teaching materials, Systematic evaluation, and Management, mobilization and social control. This paper focuses on the axis entitled Management, mobilization and social control, and aims to assess the way the subjects join the program, how they are evaluated, and how they evaluate the PNAIC. In order to analyze the teachers' adhesion to the Program, four teachers from a school in Ladário-MS, participants of the PNAIC, are interviewed. The methodology adopted is the case study, with semistructured interviews. Critical Theory is used as reference. The study concludes that teachers may not assess the Program in a negative way. The evaluation system includes questions with multiple answers, none of which leads to negative opinions about the Program. Regarding their participation, teachers do not have the autonomy to choose whether they want to join the Program or not.
\end{abstract}

Keywords: PNAIC. Adhesion. Evaluation.

Resumo: O Programa Nacional de Alfabetização na Idade Certa (PNAIC) tem como objetivo alfabetizar crianças até o terceiro ano do ensino fundamental. Subdivide-se em quatro eixos: Formação continuada, Materiais didáticos, Avaliação sistemática e Gestão, mobilização e controle social. Este texto concentra-se no eixo intitulado Gestão, mobilização e controle social. Pontua-se a maneira como os sujeitos são inseridos no programa, como são avaliados e como avaliam o PNAIC. Para analisar a concepção de adesão, são entrevistados quatro professores de uma escola de Ladário-MS, participantes do PNAIC. A metodologia adotada é o estudo de caso, com entrevista semiestruturada. Como referencial, usa-se a Teoria Crítica. O estudo conclui que os professores não podem avaliar o Programa de maneira negativa. O sistema de avaliação apresenta perguntas com respostas múltiplas, nenhuma das quais leva a opiniões negativas sobre o Programa. No que tange à adesão, os professores não têm autonomia para optar por aderir ou não ao Programa.

\footnotetext{
${ }^{1}$ Federal University of Mato Grosso do Sul (UFMS). Corumbá, Mato Grosso do Sul, Brazil.

${ }^{2}$ Federal University of Mato Grosso do Sul (UFMS). Corumbá, Mato Grosso do Sul, Brazil.
} 
Palavras-chave: PNAIC. Adesão. Avaliação.

Resumen: El Programa Nacional de Alfabetización en la Edad Adecuada (PNAIC) tiene como objetivo alfabetizar a los niños hasta el tercer año de la escuela primaria. Se subdivide en cuatro ejes: Formación continua, Materiales didácticos, Evaluación y gestión sistemática, movilización y control social. Este texto se centra en el eje titulado Gestión, movilización y control social. Se puntúa la forma en que se insertan las asignaturas en el programa, cómo se evalúan y cómo evalúan el PNAIC. Para analizar el concepto de adherencia, se entrevista a cuatro profesores de una escuela de Ladário-MS, participantes del PNAIC. La metodología adoptada es el estudio de caso, con entrevista semiestructurada. Como referencia se utiliza la Teoría Crítica. El estudio concluye que los profesores no pueden evaluar el Programa de forma negativa. El sistema de evaluación presenta preguntas con múltiples respuestas, ninguna de las cuales genera opiniones negativas sobre el Programa. En cuanto a la adherencia, los docentes no tienen autonomía para elegir si se incorporan o no al Programa.

Palabras clave: PNAIC. Adhesión. Evaluación.

\section{INTRODUCTION}

The paper is the result of a survey on PNAIC which is a formal commitment made by the Federal Governments, Federal District, states and municipalities, to ensure that all children are literate by the age of eight by the end of the third year of elementary school. From that point on, this article sought to know the conceptions of the teachers of a school in Ladario/MS about the mechanisms of authoritarianism in the adherence and evaluation of the program.

Reading the article, we find that Continuing Education in Brazil takes a much more political approach to meeting the demands of the system than the needs of the teacher and his students. In order for the teacher to develop, have a performance in the classroom and improve the learning of the student, he needs to put in first place his need as a classroom teacher, in front of that we realized during the construction of this article that what really happens is that the teacher becomes hostage of the program and participates even against his own will, as Santos points out:

[...] it is possible to affirm that, currently, the continuous formation of teachers has marked the discourse and the agenda of educational policies in the country, which, like the PNAIC, has elaborated formative proposals, which in turn are adopted by the educational systems, without, however, the marking permeates the consideration of the subjects for which these proposals are intended (SANTOS, 2015, p. 83, our translation).

There is a vision in the teachers' speeches that they are being monitored so that nothing goes wrong with PNAIC, since the adhesion so that there is one hundred percent adhesion of the 
teachers, regarding the evaluation, so that everyone positively punctuates the program so that it is seen as an exemplary government program. This way, the teacher cannot achieve what is desired.

\section{AUTHORITARIAN ADHERENCES: PNAIC AND THE MERMAIDS' CHANT}

This paper presents the teachers' conception regarding the adhesion process to the National Pact for Literacy at the Right Age (PNAIC), a commitment signed between the Ministry of Education, municipalities, State and District Secretariats, established to implement the All for Education goals plan. As the municipalities adhered to PNAIC, teachers who worked from the first to the third year of elementary school had to enter the program. In the empirical procedure of the research, we conducted interviews with 1st, 2 nd and 3rd grade teachers of a school in Ladario MS, using the recorder as a collection tool. We applied an individual semi-structured questionnaire, in order to know the teachers' conceptions regarding PNAIC. Our analysis refers to the conversations recorded with the teachers and their answers in the semi-structured interview. The questions of this interview were formulated based on the four axes of the PNAIC. The profiles of the participants were adapted as follows: Subjects ${ }^{3} 1,2,3,4$.

Let's see how the program has been adhered to by the teachers:

I first met the PNAIC in 2015, which I attended... I was called to participate, right? I had never participated before, it was the first year of formation, it was in 2015 in the municipal network in which I am working. The school... it called, you know... because... Because I'm a teacher in the cycles... then I was called to do it. (Subject 1).

The subject explains that was called to do the PNAIC for the school. Behind the word 'summoned' there is a sense of obligatory participation.

"[...] teachers became the target of a political discourse that advocated the need to assume new competencies due to the complexity of society [...]". Therefore, at each educational policy launched by the government, the teacher is responsible for his or her professionalization and/or continuing education to achieve the objectives and goals of these policies (SHIROMA; EVANGELISTA, 2003 apud CASTILHO; BEZERRA, 2016, p. 196, our translation).

Adorno, in Education and Emancipation, argues about the social contradiction that transforms the social being into a heteronomous being, "that is, no person can really exist in today's society according to their own determinations [...]" (ADORNO, 1995, p. 180-181, our translation).

\footnotetext{
${ }^{3}$ All subjects participating in the research signed the Term of Free and Informed Consent authorizing the disclosure of data that must respect the anonymity of these individuals.
} 
Faced with the need to meet the goals of the Education Plan for All, the teacher accepts what Adorno calls a 'mediating instance'. The subject ceases to exist in order to fulfill the determinations of the PNAIC. Faced with these determinations, it loses its autonomy as a teacher and assumes a non-existent role for itself, placing itself at the 'disposal' of the PNAIC. In this way:

The implementation of public policies and innovations, which are often the object of continuous training, requires the construction of a theoretical framework by teachers that broadens the possibilities of reflection on the innovations that are to be implemented. The lack of concrete conditions for effective participation results in resistance or accommodation, uncompromising the subjects of the training, with the results of such innovations (GROSCH, 2018, p. 71, our translation).

Adorno believes that there is a social transformation, in which the Cultural Industry exchanges what would be culture for goods. Everything becomes manipulable; the subject is transformed into merchandise, easier to dominate. This is evidenced in the speech of Subject 2:

Yes... initially, in 2015 , I took over the second year class, and ... the director said that I, assuming the class, would be part of PNAIC and if there was any problem, that if there was any problem... that I should let him know so that I could be get another class and they would be looking for another teacher... so that I could be participating. It was in $2015 \ldots$ and I joined initially as a listener... listener to the program. (Subject 2).

We see that a choice is imposed on the subject - either to join or to replace the teacher. That is, for the subject, the adhesion was authoritarian. Adorno asserts that there is a concern on the part of the subjects about semi-formation "[...] either with irrational contents or with conformist contents. In both cases, authoritarian traits of the personality are mobilized[...]" (ADORNO, 1995, p. 21 , our translation).

The subjects have a similar view of the PNAIC. For them, there has not been an introduction of what the PNAIC is, what it is for, or what purpose it serves (except for Subject 3, who met through the media). They were given only the duty to do it. We then asked the subjects how they felt as teachers and participants in the PNAIC. One of them informed: "It is a space that we get knowledge... of our class... of how to be conducting the teaching from the first to the third-year cycle... and .... it's a space that we have to clear doubts and update..." (Subject 1).

What we learn is that this subject sees the PNAIC as a path to follow, leaving behind all the formative knowledge previously acquired. Pena, Toledo and Kramer believe that:

In opposition to an epistemological path traditionally restricted to an relation to IIt (BUBER, 2003a), marked by the transmission of episodic and punctual contents, in which theory is disconnected from practice, and in which professors are only 
executors of proposals coming from the university or the education departments, we bet on training as an authorial process of a subject who actively builds meaning on his practice, resizing it from dialogue, experience, memory, aesthetics and ethics (PENA; TOLEDO; KRAMER, 2018, p. 2023).

We see then that it is important to know the teacher's opinion, experiences and how this formation will meet its interests.

Adorno and Horkheimer, in Dialectic of Enlightenment, recall one of Homer's narratives in which the hero meets the Mermaids and, being tied to the boat, is not seduced by their songs which would lead him to death. They say that this seductive singing has made Ulysses stuck in the dreams of the things he had lived, but everything seemed mystical, especially his past.

The authors manage to make a definition that there is a 'setting aside' of past things, as if everything were just a dream, and what really matters is what you are living or what you will live. So we compare the PNAIC to the Mermaid's song, because there is a dazzle, a seduction on the part of the teachers to think that it will be the salvation of their problems. There is a fascination on the part of the subject who lets himself be carried away by the seductions of the PNAIC, which offers him the attainment of all the goals he has to reach in education, even being aware that, to reach the goals, he will suffer oppression. We verify this state of mind in the testimony of Subject 2: "Yes, we have received training, but then the demands are higher, both for us as teachers and for the people who are accompanying, the coordinator, in this case". (Subject 2).

In addition to participating in the PNAIC training activities, the subject is monitored by superiors, who investigate whether it actually apply what is required by the program. We also see authoritarianism on the part of superiors, but the subject believes that this charge is a way to make it grow. The subject is so seduced that, even realizing that theory is not consolidated with practice, keeps participating:

Look, I like to participate of PNAIC, although it has its flaws and everything... but the question to participate of PNAIC is: to participate does not mean to interact with PNAIC, because I believe that there is a distortion between what is taught there and what we can really apply [...]. (Subject 3 ).

Even verifying that there is no junction between theory and practice, prefers to participate, because believes that it will be seen and will not be part of those who are not involved. In fact, however, it becomes a mere spectator, and does not interact with the activities of PNAIC, because it does not believe that they will work. Subject 4 also does not see the association between theory and practice: [...] it was totally different, it was more a story that was studying there... more theory, 
really. Because what I wanted was practice, and it didn't get it. (Subject 4). The observation of this subject reveals a frustration - it did not find in the formation what it expected.

In order to know the teacher's conception about the freedom to choose if it wants to act in the first grades of elementary school, we ask the subjects if the teacher who does not want to participate in PNAIC is guaranteed the freedom to act in the first three years of elementary school. We wanted to know if, in any way, the teacher who does not adhere to PNAIC is prevented from acting as a teacher during those years. This is how Subject 1 manifested itself: "What I hear in my work is that if you are a first, second and third year teacher, you have to join PNAIC and if you don't join the Program, you are taken out of these classrooms". (Subject 1).

The subject, here, uses the explanation of others to place itself as neutral before the answer, which shows that the subject is retreating to say what really happens in its school.

The subject is not at ease to say what he really thinks about the tax participations of PNAIC. What no longer happens with Subject 2: "This is bad, because if you took the first, second and third years, you are automatically obliged to do the PNAIC. You have no choice, you must do the PNAIC". (Subject 2).

This subject manifest a revolt, seeing that it has no option to choose whether or not to participate in the PNAIC. Another item it emphasizes is that there is no respect for its identity as a teacher. The imposition of PNAIC, then, transforms the subject into an object, determining its acceptance of the social and cultural impositions imposed. Thus, the subject ceases to be emancipated, in order to accept what is considered obligatory. We also see this in the speech of Subject 3:

Teachers are summoned... if they want to work in the first, second and third years, they must do the PNAIC. So much so that this year, there was a discussion. I said that I wouldn't do it and I was in the second year and the principal wanted to replace my classroom and I said that I would not replace it, I would not replace it. (Subject 3).

Adorno considers that, when there is a breach of the obedience of impositions, of those who in some way want to exercise authority, the subject succeeds in freeing himself from the bonds established by the mechanisms of domination. Subject 3 breaks this barrier of impositions and is free to choose between doing or not doing the PNAIC. Again, the question of imposition is on the agenda in Subject 4: "The orientation is very clear on the first day, that if you don't adhere to the PNAIC, that you are speaking of, another teacher will be referred". (Subject 4). 
If the subject does not belong to the effective network of the municipality, then the barbaric act of "replacing" terrifies it. The authoritarian attitude on the part of the superiors makes the subject submissive to the desires of those responsible for the school, who must oblige the teachers to participate, and those responsible for PNAIC, who must, in any case, respond positively to the Ministry of Education.

\subsection{AUTHORITARIAN EVALUATION AND CONTROL AS A PROCESS OF TUTELAGE}

Nowadays, the subject has lost its autonomy, as a thinking being capable of making its own decisions. It has become a subject seen as a "thing", a product of cultural goods. As everything is transformed into merchandise, the market is full of subjects who are at disposal. However, there is a marketing need to create mechanisms of control, directly or indirectly, for without them the subject can begin to act according to its own conscience. This power of control is so strong that the subject, even knowing that it is being controlled, cannot free itself from the bonds for fear of not finding space in the labor market. Thus, it starts to assume a role of something, a mere object in the hands of the rulers. On this theme, we find in Adorno's authoritarian Personality, the description of the authoritarian man that arises, not from political and cultural ideologies, but from the impotence of the individual to go against them. This subject compensates its weakness by identifying with its oppressors, because it believes that only through power will it be able to overcome its ignorance. Adorno characterizes this subject: "He is both enlightened and superstitious, proud of being an individualist and always fearful of not being equal to others, jealous of his independence and inclined to submit blindly to power and authority" (ADORNO, 2006, p. 01, our translation).

There is, in the PNAIC, an axis, specifically axis 4, on management, mobilization and social control. In the very objective of the PNAIC, there is the designation of having social control, which is only done through evaluations. We inquire about the conceptions of teachers in relation to these evaluations. We ask if they are evaluated by the program, and in what way.

According to one of the subjects: "Yes, I believe that because of the tasks they make available for us to do, the punctuality, the report that we have to present, I think it is a form of evaluation, and the participation in the courses that I present... for the participation". (Subject 1).

The subject is controlled in several ways, by punctuality, by the report, by participation, among other forms of control. The control is carried out as that of a factory employee, who has to 
record entry and exit times, record what is produced. In order to escape from this control, the subject must be clarified.

What Adorno reveals is that, in the face of so many pressures and controls produced by the cultural industry, the subject cannot act according to its own will, so it is no longer an enlightened subject. The subject is always controlled in its practice. In this way Roveri points out:

Therefore, it is necessary to pay attention to a field of tension around the curriculum, evaluation and teacher training, a fact that not only brings the risk of homogenization of pedagogical practices but also fuels the blaming of teachers for the expected results of their students, shaking the construction of close relationships between the different stages of Basic Education (ROVERI, 2019, p. 268 , our translation).

There is a fear, in the speech of this subject, that even in its responses to student learning, is being monitored. It is frightened, because it knows that it is also being evaluated through the answers. This way the subject blames itself for the negative result achieved by the student.

There is a false freedom (offered by the controllers) during the production of their work, but in the end, the subject is evaluated if it was able to achieve the results of what was required. "The exponential increase of bureaucratic arrangements in the exercise of the profession should not be seen as a mere technical or administrative matter, but rather as the emergence of new forms of government and control of the profession" (NÓVOA, 2009, apud RAIMUNDO; FAGUNDES, 2018, p. 1941, our translation).

It is fundamental that the teacher learns what will be important and adds to its training in order to pass on the knowledge to its students. In this way:

The superficiality found in the continuous formation is a characteristic of capitalism in today's Brazilian society, because, by weakening the teacher's knowledge in these courses, the State aims at practices that are in line with the legitimization of the established social order, considered natural, unalterable (BARROS; VICENTINI, 2018, p. 1955, our translation).

According to Adorno: "The formal freedom of each one is guaranteed. No one should officially realize what they think. In exchange, everyone is locked up, from beginning to end, in a system of institutions and relationships that form a hypersensitive instrument of social control" (ADORNO, 2002, p. 06, our translation).

For the author, formal freedom is set so that the subject believes that is free to do what it wishes. However, in the end, it will be evaluated by the social control tool. Subject 4 confirms what 
the others said: "I attended! For the participation in the course and the work done in the school". (Sujeito 4).

Under this control, the subject is inhibited to develop what it believes gives results. It gives visibility to what has been passed on to it, to convey the information that the PNAIC is having a return.

We ask teachers what they think and how they feel about the technical visits of study advisors and supervisors in their classroom, that is, about the process of monitoring their teaching activities:

[...]It is, many times it is a form only of billing, that you see that some... not generalizing, but some are more to be seeing if you are fulfilling, if you are doing, not with the stamp of... - Ah, I am here to help you! (Subject 1).

Teachers see these visits as monitoring, a way of knowing if the teacher is working as determined by PNAIC. Teachers understand that even what would be an orientation visit becomes a way to monitor them. Even when it is not at school during its period, it is observed, as explained by Subject 2: "There were not these visits, this follow-up, not in my class period, that the technique, the coordinators, had yes in the school, but in the opposite period, so I can't say... because I didn't receive any visits this year". (Subject 2).

This teacher believes that it was not monitored due to the fact that supervisors did not visit it in its class period. This speech leads to the belief that the subject does not understand why it has not been inspected, i.e., a questioning occurs when the subject is not assisted, or tutored, because it feels the lack of control. People feel the need for an endorsement to say whether it is right or wrong, whether it is proceeding as it was imposed. We realize this in Adorno's argument about the dependence on science: "People believe they are safe when they guide themselves according to scientific rules, obey a scientific ritual, surround themselves with science" (ADORNO, 1995, p. 69, our translation).

We see, in Adorno, the explanation that the subject becomes so submissive to science, that it cannot look at what it is in fact, without the endorsement of science. This also occurs with the subjects who cannot evaluate their work as teachers without the supervisor's evaluation. When this control does not occur, they get upset. The lack of supervision and inspection made Subject 3 outraged: "I don't mind the visits, I just think... that it could be in another way, in a more collaborative way, and not just by charging... right, that's the situation, supervision [...]". (Subject 3). 
There is a complaint on the part of this subject regarding the lack of cooperation from its supervisors. It does not want to be charged, but only the tutelage. The subject is so hostage to this tutelage that, when it is monitored, a feeling of revolt, of non-understanding, invades.

The subjects question the technical visits, since they were only meant to observe the work of the teacher, who felt oppressed by the demands. We see that the lack of tutelage makes the subject complain, because it is being charged, and does not see the help from the tutors of PNAIC. The teacher sees that control is a way to fulfill all the proposed activities, as well as the organization of its classroom and the school environment in general. We could see this more clearly when we asked the teachers to tell us what they thought and how they felt about the process of controlling their participation: "I am hired, so I need to participate in what is placed, and I try to solve it in the best possible way [...]". (Subject 1).

This subject clearly fears to lose its job, for this reason it does everything that is imposed. The subject ceases to exist in order to fulfill what has been demanded, losing all autonomy.

People go through so much pressure lately that their emancipation is no longer legitimized. This control leaves the subject with no choice. It imposes on the subject the obligation to be present at the trainings and to do the activities required by the PNAIC, as we confirm with Subject 3 :

This control... this year was a little more complicated. They kept collecting our activities, because they have... now the coordinators have access... they keep collecting, collecting, but they never give a better support... why don't they speak? why don't they explain? Why? Why are we doing this? For me, what they do is just the bureaucratic, really. (Subject 3).

For this subject, the objectives of the activities proposed by PNAIC were not disclosed. Therefore, its participation in the training becomes involuntary and oppressive. From the moment the subject is obliged to participate in the activities and is constantly charged, it participates in the formations involuntarily, which becomes an oppression and legitimizes barbarity. The subject concludes that these activities and its participation are nothing more than something bureaucratic, in which it must show results: "It was by call. It was a bit of pressure, not total free will". (Subject 4).

The subject felt pressured. It clearly shows that it participated, more by obligation than by free and spontaneous will. The subjects appear to be participating moved by their own interests, but involuntary participation. Adorno ponders: "Culture has always contributed to tame revolutionary instincts as well as barbaric customs" (ADORNO, 2002, p. 31-32, our translation).

The acceptance behavior is an automatic attitude. At the subject's core, there is a revolt contained by methods of oppression, methods used to discipline and make exemplary victims. 
Culture has this role of controlling the rebels. Faced with this control/domain, we ask teachers to tell us what they think and how they feel about the process of control of their activities, to which they replied: "Many times you don't have your own autonomy in the room, but... we don't have autonomy". (Subject 1). The subject responds, initially, then thinks better and concludes that it does not have autonomy. Only when questioned, awakens and realizes that itdoes not have autonomy over its classroom activities.

The subject was uncomfortable with visits from supervisors, who only observed the physical aspect of their classroom, the organization of the environment and not what the students had developed and learned in this alphabetizing environment:

This year we had no control of the activities carried out, but in previous years, [...] they came with a supervisory role to ask... if... they practically looked at the decoration of the classroom, if it was decorated, all right. But they didn't ask for activities, tests or ask to see the children's notebook or anything. (Subject 3).

That is, what you see is worth much more than what it really is. Organizing the "learning corners" becomes much more useful than the notebooks with the students' productions. Adorno, in his talk regarding the backstage of television, shows that there is a concern among teachers to show that they are producing, that they are using PNAIC material. What would be to show the reality becomes a merchandise of the product. The backstage, those who are behind the whole show, do not appear. What is presented are perfect activities and rooms, as if there were no problems or difficulties, as if everything that revolves around PNAIC is perfect. The students and their disabilities are hidden behind the scenes, the teachers and their difficulties too.

Among the subjects researched, we find one who claims to have autonomy: "I had autonomy to do, so I had no supervision, I was free to do, according to the student's needs, on top of the PNAIC material". (Subject 4). The subject believes to have autonomy, which works with the needs of the students, but is attached to the material of PNAIC. We have, thus, a pseudo-reality, because the subject believes it has autonomy in its classroom but is obliged to use and show results in the end.

We know that these teachers were constantly evaluated by a control tool called SISPACTO, created by PNAIC, through INEP, which evaluates coordinator, trainer, supervisor, advisor and teacher. We asked the teachers if this evaluation respected their anonymity. One of them pointed out: "I believe not! Because everyone has their own page and the tutor opens your page with your password and she sees what you put there... so..." (Subject 1).

The subject is aware that its anonymity is not maintained. Through the SISPACT, its supervisors have access to its answers. Thus, with the "so..." it is understood that there is a control 
behind the tool. Subject 2 reacted in a similar way: "No!!! Because, for you to have access, you need to identify yourself, you enter, you have your password... so... from the moment you identify yourself, you have the name, a password and a CPF, so you have no anonymity". (Subject 2).

From the moment personal documents are used to register in the " network ", the subject instantly loses its anonymity. The subject ceases to be anonymous and becomes visible to the supervisors, which causes certain fear to the subjects: "No! Because... this way... they all access the SISPACTO, access our name, then... everybody knows who guided who and who gave the grade to whom. Right!". (Subject 3).

The trainers and their supervisors have access to the teachers' responses and know who has developed the PNAIC well and who has not, due to the grades and concepts seen in the SISPACTO.

Most teachers believe that since they can access the name, documentation and password, there is no anonymity: the other has access to their data and becomes aware of their scores, whether they are grades or about their opinions. Due to the disruption of anonymity, we asked if the teacher felt free to express its opinion in SISPACTO: "Many times not, because you already have a line of thought formed, determined and that you have to adapt". (Subject 1).

The teacher finds, in SISPACTO, objective and direct questions, considering that the answers are always positive, that is, there is a predetermination for possible answers. The subject does not insert negative answers, because its known that they will be visualized by the trainers of the PNAIC: "you must answer, even without agreeing". (Subject 2).

The questions are positively inductive, so that the subject answers, even without agreeing. We realize that, in the evaluation system itself, there is a coercive induction, so that the subject punctuates only what is imposed.

When there is a manipulation before the data and there is no rationalization of the subject regarding the results, this subject remains irrational. By the teachers' answers, since it is visibly put what it is to classify in SISPACTO, only remains to classify and send. For Subject 3: "Well, I feel at ease... because I am a sincere person, what I have to say I say... I feel at ease to evaluate the SISPACTO". (Subject 3).

The subject is convinced that they are capable of transposing the evaluation policy of the PNAIC and evaluate normally, without the imposition of the system and its tutors. We believe that this thinking reflects much of the person's personality, of the subject disposition and of the force that dominates this personality that faces the governing politics. Adorno, in Authoritarian Personality, reports: "The forces of the personality are first of all needs (instincts, desires, emotional 
impulses) that vary from one individual to another in quantity, intensity, mode of gratification and objects of fixation" (ADORNO, 2006, p. 05, our translation).

The "forces of the personality" change according to the subject's needs. The subject may somehow find this assessment normal, because it feels comfortable, or not to go against what is imposed and suffer retaliation.

Therefore, we ask the subjects, if they know what happens if they evaluate the PNAIC well, we observe the answers: "Well... you get a good grade..." (Subject 1). The subject trusts that if it evaluates positively, will receive the compensation through a good score in the SYMPACT. This compensation is also seen in the speech of Subject 2: "Well, if you evaluate well, I believe that as if you earn points or have this way fit to the program, as if it were so ... pleasing a system to a manager". (Subject 2).

PNAIC is well evaluated, the subject feels as if it has been rewarded, fit for work. It feels good about pleasing a system, something that manages it, as if the oppressed feels satisfaction in pleasing the oppressor. There is a sadomasochistic attitude behind this submission to the system - the subject feels pleasure in being tortured.

In the statement of Subject 3, we noticed the issue of the financial bonus: "In the case, if I evaluate well, everyone receives the scholarship, this is the ... the good evaluation everybody receives, evaluating badly, I don't know how to tell you what happens". (Subject 3). It is believed that if they evaluate PNAIC positively, their compensation will be through the receipt of the scholarship in the amount of $\mathrm{R} \$ 200$ reais, made available by MEC to the students.

The scholarship provided by PNAIC becomes one of the reasons for the positive evaluation: the subject imagines that if it does not evaluate the PNAIC positively, it will be cancelled. It seems that part of these teachers participates and evaluate positively in order to receive the financial resource.

We asked the subjects, what would happen if they badly evaluated the program in SISPACTO. Then one subject said: "Your grades fall, and I think... I don't know, I always put it there well". (Subject 1). The subject is not sure if the grades decrease, because always evaluated the PNAIC positively. This is noticed in the speech of all the subjects: "I don't know... some were very few. Sometimes the answers are yes, no and sometimes, [referring to the ready answers that the program offers for the evaluations], then it doesn't appear like this... - or you did such a thing or not!". (Subject 2). 
As we have observed, these responses have been formulated to receive a positive response. There is no space, within the SISPACTO, for the subject to put its opinion about the PNAIC. Subject 3 said: "I don't know... I have never evaluated like this, I have always put the truth like this, which is in accordance with reality, but I have never known of any penalty, that they suffered or that anything happened". (Subject 3). This subject, who assumes to respond the way it perceives reality, has not negatively evaluated the PNAIC. Therefore, it creates an uncertainty, that it does not even know what the result of the negative evaluation will be. And the answer follows with Subject 4: "No, until then I never evaluated badly, I was always in the average". (Subject 4).

Adorno presents the idea that the system follows an addictive reproduction cycle. From the answers to the questions, we saw that the teachers do not evaluate as they would like, even saying that the program does not meet the reality of their classroom. Instead, they evaluate PNAIC well, which keeps reproducing its "literacy formulas". This whole process is made up by the teachers, who stop evaluating, because the PNAIC does not offer, in the evaluation system, a field to hear the teachers' opinion, and even because these teachers, for fear of retaliation, stop complaining to their tutors. In this way, everything seems to be going well.

Regarding the systematic evaluation, the teacher believes that there is a failure, because they cannot position PNAIC negatively, even because this system does not offer this option, so the teacher is at the mercy of the answers contained in the system, these are always positive characteristics to demonstrate that everything is happening well and that there is mass acceptance of the teachers to PNAIC. As for management, mobilization, and social control, the teacher finds itself controlled, obliged to participate and reproduce the activities required by PNAIC, thus it loses its autonomy and becomes bound by the impositions of PNAIC. In brief, we believe that teachers need to break through the barrier of imposition. They need to be autonomous enough to decide which direction they want to take to build their intellectual formation. Barbarism, imposed on teachers every day, generates people alienated and distant from emancipation.

\section{FINAL CONSIDERATIONS}

In the construction of this paper, we sought to investigate, through analysis, the conception of teachers about the mechanisms of authoritarianism in the implementation of PNAIC in the organization of teaching work, in relation to adherence and Management, mobilization and social control. 
In the Critical Theory of Adorno, there are deepening regarding education against barbarism. The author defends that, only through education, the subject will no longer be tutored to become an enlightened subject, capable of being led by its own thought constructions, without letting itself be led by imposed ideas or pre-established ideals. Adorno awakens us to the awareness that Education, Formation and Emancipation are entirely linked and that it is through these three elements that the subject becomes enlightened. However, more specifically when writing about how to elaborate the past, Adorno states the idea that there is no way to experience the present without reviewing the past. The author warns of the bourgeois ideals that make society forget the past, not because of the many stimuli existing today, but because of the system, which is calculated to leave no remains.

From what we saw in the teachers' speech we clearly realized that they leave aside what they had learned to receive the 'new' without questioning whether this was really what they were needing in their formation. We also realized that they adhere to the program in a coercive way, because it is put to them that they must participate in the program or they will be excluded from the grades that are part of PNAIC.

Regarding themes such as evaluation, management, mobility and social control, teachers know that they are controlled and evaluated within a system that contains questions directed to a single answer: that the PNAIC works and that its objectives are being achieved. The teacher feels the target of so many demands and evaluations of its pedagogical performance that it ends up frustrating for not being able to reach the actions that were imposed on it.

\section{REFERENCES}

ADORNO, T. W. Educação e emancipação. São Paulo: Paz e Terra, 1995.

ADORNO, T. W. Indústria cultural e sociedade. São Paulo: Paz e Terra, 2002.

ADORNO, T. W.; BRUNSWIK, E. F.; LEVINSON, D. J. Y R.; SANFORD, N. La personalidad autoritaria. Empiria Revista de Metodología de Ciencias Sociales, n. 12, p. 155-200, jul./dez. 2006.

BARROS, M. S. F.; VICENTINI, D. A Epistemologia Dialética na Atividade Pedagógica: Realidade e Possibilidade na Formação do Professor Da Infância. Revista Ibero-Americana de Estudos em Educação, Araraquara, v. esp., n. 3, p. 1952-1963, dez. 2018.

CASTILHO, T. B.; BEZERRA, G.F. Educação Especial e Inclusão Escolar Nos Cadernos do Pacto Nacional pela Alfabetização na Idade Certa. Revista Tempos e Espaços em Educação, São Cristóvão, v. 9, n. 19, p. 193-208, maio/ago. 2016. 
GROSCH, Maria Selma. Ação Humana, Atividade Docente e Formação Continuada de Professores: Perspectivas a Partir do Pensamento de Hannah Arendt. Revista Tempos e Espaços em Educação, São Cristóvão, v. 11, n. 25, p. 71-82, abr./jun. 2018.

KOVACS, Helena; TINOCA, Luís. Unfreeze the pedagogies: introduction of a new innovative measure in Portugal. Revista Tempos e Espaços em Educação, São Cristóvão - SE, v. 10, n. 23, p. 73-86, 2017.

PENA, A.; TOLEDO, L.; Sonia, K. Eu Fiz um Esquecimento do meu Passado de Professora: Memória, Narrativa e Experiência Como Caminho Epistemológico na Formação de Professores. Revista IberoAmericana de Estudos em Educação, Araraquara, v. esp., n. 3, p. 2008-2025, dez. 2018.

RAIMUNDO, J. A.; FAGUNDES, M. A Epistemologia da Práxis como Fenômeno Formador do/a Docente: Um Caminho Possível? Revista Ibero-Americana de Estudos em Educação, Araraquara, v. esp., n. 3, p. 1935-1951, dez. 2018.

ROVERI, F. T. Ensino Fundamental de nove anos: rupturas com a Educação Infantil ou acolhimento das infâncias? Revista Tempos e Espaços em Educação, São Cristóvão, v. 12, n. 28, p. 263-278, jan./mar. 2019.

SOUSA, Jesus Maria. Repensar o currículo como emancipador. Revista Tempos e Espaços em Educação, São Cristóvão - SE, v. 9, n. 18, p. 111-120, 2016.

\section{ABOUT THE AUTHORS:}

\section{Crisley Monteiro Olarte}

Master's in education, Federal University of Mato Grosso do Sul (UFMS) - Brazil.

E-mail: crisleymolarte@gmail.com

ORCID: https://orcid.org/0000-0002-6600-2207

\section{Isabella Fernanda Ferreira}

Permanent Professor of the Post-graduate Program in Education, Federal University of Mato Grosso do Sul (UFMS) - Brazil. Doctorate in Education (UNESP/FCLAr).

E-mail: bella.fernandaferreira@gmail.com

ORCID: https://orcid.org/0000-0001-5356-5767 